\title{
Studies on Extent of Variability, Heritability and Genetic Advance in Okra [Abelmoschus esculentus (L.) Moench]
}

\author{
Shalu Yadav*, Vijay Bahadur Singh, Gulab Chand Yadav and Aniket Kumar Verma \\ Acharya Narendra Deva University of Agriculture \& Technology, Kumarganj, \\ Ayodhya, Uttar Pradesh, India \\ *Corresponding author
}

\section{A B S T R A C T}

\section{Keywords \\ Variability, PCV, GCV, Heritability, Genetic advance, Okra (Abelmoschus esculentus (L.) Moench)}

\section{Article Info}

Accepted: 04 September 2020 Available Online: 10 October 2020
The experiment was conducted at Main Experimental Station, Department of Vegetable Science, Acharya Narendra Deva University of Agriculture and Technology, Kumarganj, Ayodhya during Kharif, 2019 in Randomized Complete Block Design with three replications using thirty -six genotypes of okra collected from different sources to study the extent of variability, heritability and genetic advance in per cent of mean for different quantitative traits. The analysis of variance for the design of experiment indicated highly significant differences among the genotypes for all the characters. Based on mean performance of genotypes NDO-37 (210.79) followed by NDO-26 (209.33), NDO-27 (199.41), NDO- 31 (208.97) and NDO-36 (209.12) were found as five most promising genotypes for fruits yield per plant. High magnitude PCV were observed in case of number of branches per plant (16.23) followed by fruit length (9.91), total fruit yield per plant (9.36). High heritability was estimated for total fruit yield per plant (99.3) followed by average fruit weight (93.86), petiole length (92.80) number of branches per plant (84.54). High heritability coupled with high genetic advance were estimated for number of branches per plant $(84.54,28.27)$ followed by total fruit yield per plant $(99.13,19.11)$ and average fruit weight $(93.86,14.29)$ which indicating opportunity for high selection response.

\section{Introduction}

Okra [Abelmoschus esculentus (L.) Moench $2 n=2 x=130]$ is one of the important member of the family malvaceae and is well known by many regional names as lady's finger in England, Gumbo in USA, Dherosh in Bangladesh, Huang GiuKui in China, Quingombo in Spanish, Bhindi in Pakistan and India. Okra is an African word and is native to northern Africa including the area of
Ethiopia and Sudan. It is a summer and rainy season crop and is widely cultivated from tropics to sub tropics. Okra (Abelmoschus esculentus L.) is probably an amphidiploids (allotetraploid) derived from Abelmoschus tuberculatus $(2 \mathrm{n}=58)$, a wild species from India, and a species (Abelmoschus ficulneus (L.) Wight and Arn. ex Wight) with $2 n=72$ chromosomes. According to Vavilov, it was probably domesticated in the Ethiopian region but, according to Murdock, it is originated in 
West Africa (Joshi et al., 1974). Okra was earlier included in the genus Hibiscus, section Abelmoschus in the family malvaceae (Linnaeus, 1753). The wider use of Abelmoschus was subsequently accepted in the taxonomic and contemporary literature. This genus is distinguished from the genus Hibiscus by the characteristics of the calyx, spathulate, with five short teeth, connate to the corolla and caducous after flowering (Kundu and Biswas, 1973 and Terrell and Winters, 1974).The future and prospect of any breeding programme depend on the extent of variability present in the population. Hence, assessment of genetic variability in the base population is the foremost step in any breeding programme. In present investigation attempt has been made to assess the variability of important yield and yield attributing traits, along with the indices of variability i.e. GCV, PCV, heritability (broad sense) and genetic advance.

\section{Materials and Methods}

The research work was undertaken at the Main Experimental Station, Department of Vegetable Science, Acharya Narendra Deva University of Agriculture and Technology Narendra Nagar (Kumarganj), Ayodhya (U.P.) during the Kharif, 2019. Geographically the experimental site (Kumarganj, Ayodhya) falls under humid sub-tropical climate and is located at $26.47^{\circ} \mathrm{N}$ latitude and $82.12^{\circ} \mathrm{E}$ longitude at an altitude of 113 meter above the mean sea level. The experiment was conducted in Randomized Complete Block Design with three replications to assess the performance of thirty genotypes. Observations were recorded on thirteen quantitative characters viz. days to $50 \%$ flowering, node to first flower appearance, plant height $(\mathrm{cm})$, crop duration, number of branches per plant, days to first fruit harvest, fruit length $(\mathrm{cm})$, fruit circumference $(\mathrm{cm})$, average fruit weight, number of fruits per plant, marketable fruit yield per plant $(\mathrm{g})$, unmarketable fruit yield per plant $(\mathrm{g})$. The analysis of variance was carried out as per Panse and Sukhatme (1984), genotypic and phenotypic coefficient of variance by Burton and de Vane (1953), heritability and genetic advance as per method suggested by Hanson et al., (1963) and Johnson et al., (1955), respectively.

\section{Results and Discussion}

The analysis of variance for different characters has been presented in Table 1 . The mean sum of square due to genotypes were highly significant for all the characters. In other words, the performances of the genotypes with respect to these characters were statistically different, suggesting that, there exists ample scope for selection in the available genotypes of okra. The mean performances of genotypes under studies are presented in Table 2 which shows the extent of variation in average performance among the genotypes for the quantitative traits. The best five genotypes which significantly out yielded the check varieties on the basis of mean performance for fruit yield were NDO37, NDO-26, NDO-27, NDO-35 and NDO36 . These genotypes may further evaluate for yield performance towards development of new improved varieties of okra in future.

The genotypic and phenotypic coefficients of variation were computed to assess the existing variability in available germplasm (Table 3). High magnitudes of phenotypic as well as genotypic coefficients of variation were observed in number of branches per plant followed by total fruit yields per plant, fruits length and number of fruits per plant. The high estimates of PCV and GCV for these characters were also reported by Kerure et al., (2017) and Chandramauli et al., (2016). Moderate PCV along with GCV were recorded for fruit circumference followed by 
node to first flower appearance and node per plant. While, low GCV and PCV were observed for days to first fruit harvest followed by plant height, node per plant. Moderate and low variability were also reported by Hazra and Basu (2000) and Narayan et al., (2006).

The result on heritability and genetic advance in per cent of mean of present investigation had been presented in Table 3. The heritability estimates for different characters ranged from 10.03 to 99.13 per cent. High estimate of heritability was recorded for characters total fruit yield per plant, average fruit weight, petiole length days to $50 \%$ flowering, fruit circumference number of branches per plant.

High estimate of heritability was also reported by Naidu et al., (2007). The maximum genetic advance in per cent of mean showed in number of branches per plant fallowed by total fruit yields per plant, fruit length and fruit circumference. Similar results have been reported by Kerure et al., (2017). High heritability coupled with high genetic advance was observed for the traits viz. total fruit yield per plant, average fruit weight and petiole length which indicates the opportunity for selection response in available germplasm of okra. High heritability along with high genetic advance have also been reported for most of the yield and yield attributing traits by Chandramauli et al., (2016) and Patel et al., (2014).

Thus, it may be concluded that considerable variability exists within the genotypes of okra. The, genotype NDO-37 followed by NDO-26, NDO-35, NDO-36 and NDO-27 were found promising for total fruit yield per plant and other traits and may further evaluated to develop as variety. High heritability along with high genetic advance for important traits viz. total fruit yield per plant, average fruit weight and petiole length indicated greater chance of selection response.

Table.1 Analysis of variance for thirteen characters in okra

\begin{tabular}{|c|c|c|c|c|}
\hline \multirow[t]{3}{*}{ S.No. } & \multirow[t]{2}{*}{ Characters } & \multicolumn{3}{|c|}{ Source of variation } \\
\hline & & Replication & Treatment & Error \\
\hline & d.f. & 2 & 35 & 70 \\
\hline 1. & Node to first flower appearance & 0.28 & $32.58 * *$ & 7.25 \\
\hline 2. & Days to $50 \%$ flowering & 2.78 & $390.33 * *$ & 48.59 \\
\hline 3. & Days to first fruit harvest & 7.41 & $323.88 * *$ & 139.26 \\
\hline 4. & Fruit length $(\mathrm{cm})$ & 4.09 & $178.97 * *$ & 30.38 \\
\hline 5. & Fruit circumference $(\mathrm{cm})$ & 0.03 & $27.20 * *$ & 3.48 \\
\hline 6. & Plant hight $(\mathrm{cm})$ & 216.00 & $2702.21 * *$ & 2165.08 \\
\hline 7. & Number of branches per plant & 0.06 & $25.94 * *$ & 2.98 \\
\hline 8. & Crop duration (days) & 88.91 & $1059.21 * *$ & 3233.76 \\
\hline 9. & Petiole length $(\mathrm{cm})$ & 0.01 & $67.09 * *$ & 3.39 \\
\hline 10. & Average fruit weight $(\mathrm{g})$ & 0.22 & $224.14 * *$ & 9.54 \\
\hline 11. & Node per plant & 3.75 & $160.09 * *$ & 239.49 \\
\hline 12. & Number of fruits per plant & 2.57 & $53.44 * *$ & 80.09 \\
\hline 13. & Total fruit yield per plant (g) & 10.66 & $31692.86^{* *}$ & 186.67 \\
\hline
\end{tabular}

** Significant at 1 percent probability level 
Table.2 Mean performance of thirty-six genotype of okra

\begin{tabular}{|c|c|c|c|c|c|c|c|c|c|c|c|c|c|c|}
\hline $\begin{array}{l}\dot{Z} \\
\dot{\Omega}\end{array}$ & Genotypes & 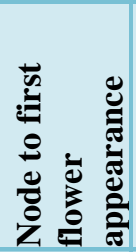 & 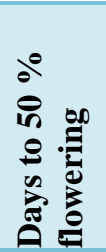 & 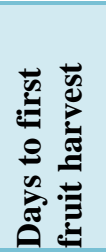 & 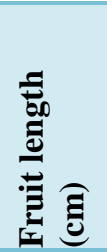 & 节 & 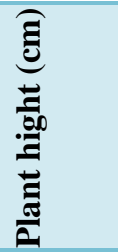 & 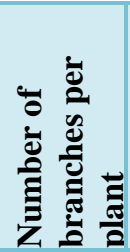 & 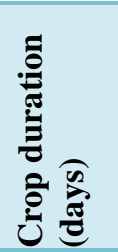 & 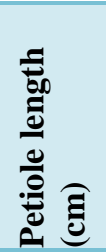 & 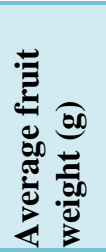 & 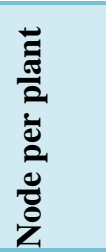 & 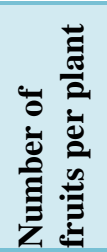 & 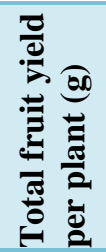 \\
\hline 1 & NDO-21 & 6.83 & 41.67 & 54.33 & 12.18 & 6.30 & 106.41 & $3 . \overline{63}$ & 96.67 & 14.38 & 18.16 & 22.34 & 12.00 & 183.96 \\
\hline 2 & NDO-22 & 7.64 & 42.00 & 53.00 & 11.86 & 6.34 & 116.60 & 3.27 & 103.00 & 13.19 & 17.76 & 22.60 & 12.00 & 185.71 \\
\hline 3 & NDO-23 & 8.06 & 43.00 & 54.33 & 15.57 & 5.49 & 115.63 & 3.61 & 102.33 & 12.87 & 21.05 & 21.23 & 11.33 & 185.67 \\
\hline 4 & NDO-24 & 7.69 & 42.67 & 52.67 & 14.36 & 5.56 & 112.00 & 2.89 & 101.67 & 14.77 & 19.50 & 21.63 & 11.00 & 180.67 \\
\hline 5 & NDO-25 & 6.88 & 45.67 & 54.67 & 12.74 & 6.33 & 110.07 & 2.33 & 102.67 & 14.74 & 21.49 & 21.37 & 10.67 & 205.33 \\
\hline 6 & NDO-26 & 7.36 & 42.67 & 53.67 & 11.63 & 6.40 & 117.60 & 2.67 & 98.33 & 13.89 & 19.59 & 23.41 & 13.33 & 209.75 \\
\hline 7 & NDO-27 & 7.39 & 47.00 & 56.00 & 12.60 & 5.56 & 119.12 & 3.52 & 103.00 & 13.41 & 22.24 & 21.97 & 11.67 & 199.41 \\
\hline 8 & NDO-28 & 7.88 & 48.67 & 57.00 & 14.67 & 5.66 & 114.59 & 3.83 & 99.33 & 12.67 & 19.78 & 23.01 & 11.00 & 175.75 \\
\hline 9 & NDO-29 & 6.92 & 45.33 & 56.00 & 15.52 & 6.41 & 119.26 & 3.55 & 102.67 & 12.78 & 22.00 & 22.71 & 12.67 & 170.93 \\
\hline 10 & NDO-30 & 7.70 & 44.33 & 56.00 & 14.30 & 6.30 & 115.07 & 3.63 & 103.67 & 14.81 & 22.93 & 23.52 & 12.00 & 186.14 \\
\hline 11 & NDO-31 & 7.84 & 47.00 & 56.67 & 15.60 & 6.54 & 121.19 & 3.28 & 98.67 & 14.78 & 21.63 & 20.63 & 12.00 & 208.97 \\
\hline 12 & NDO-32 & 6.77 & 43.67 & 54.00 & 14.26 & 5.84 & 108.79 & 3.52 & 103.00 & 14.45 & 18.88 & 23.08 & 11.67 & 181.41 \\
\hline 13 & NDO-33 & 6.77 & 46.00 & 55.33 & 16.37 & 5.43 & 119.93 & 3.85 & 103.67 & 13.78 & 17.82 & 22.71 & 13.00 & 175.82 \\
\hline 14 & NDO-34 & 7.53 & 47.33 & 55.67 & 12.59 & 6.55 & 114.56 & 3.64 & 102.67 & 13.30 & 20.56 & 24.26 & 12.67 & 189.45 \\
\hline 15 & NDO-35 & 7.38 & 44.00 & 55.33 & 16.11 & 5.42 & 116.52 & 3.89 & 94.33 & 13.41 & 22.40 & 22.92 & 11.33 & 207.45 \\
\hline 16 & NDO-36 & 8.02 & 47.33 & 57.33 & 16.26 & 5.38 & 113.33 & 3.85 & 96.33 & 14.88 & 19.56 & 23.10 & 12.00 & 209.12 \\
\hline 17 & NDO-37 & 6.61 & 42.67 & 54.00 & 13.97 & 5.49 & 111.62 & 3.88 & 105.00 & 13.26 & 19.64 & 23.27 & 12.67 & 210.79 \\
\hline 18 & NDO-38 & 6.19 & 43.33 & 54.33 & 13.46 & 6.66 & 116.00 & 3.45 & 99.67 & 13.71 & 19.69 & 22.18 & 13.00 & 208.32 \\
\hline 19 & NDO-39 & 6.81 & 42.33 & 53.33 & 13.84 & 6.67 & 110.69 & 2.74 & 105.67 & 12.73 & 22.24 & 22.78 & 11.67 & 202.52 \\
\hline 20 & NDO-40 & 7.64 & 45.00 & 55.00 & 14.55 & 6.38 & 114.25 & 2.89 & 102.00 & 12.60 & 21.37 & 23.41 & 12.00 & 205.23 \\
\hline 21 & NDO-41 & 6.41 & 46.67 & 57.00 & 15.71 & 6.38 & 107.59 & 2.52 & 102.00 & 13.79 & 21.45 & 22.89 & 13.67 & 191.23 \\
\hline 22 & NDO-42 & 7.38 & 43.00 & 54.00 & 14.26 & 5.77 & 109.15 & 2.58 & 106.33 & 13.40 & 18.80 & 22.30 & 11.67 & 186.51 \\
\hline 23 & NDO-43 & 7.03 & 44.67 & 53.00 & 13.48 & 6.41 & 117.97 & 2.82 & 97.67 & 12.77 & 19.45 & 22.71 & 12.00 & 165.59 \\
\hline 24 & NDO-44 & 7.74 & 43.67 & 54.00 & 14.59 & 5.37 & 121.23 & 2.72 & 105.33 & 12.64 & 20.57 & 22.41 & 12.67 & 165.63 \\
\hline 25 & NDO-45 & 7.37 & 42.00 & 53.00 & 15.37 & 6.49 & 112.41 & 3.63 & 108.33 & 12.53 & 21.67 & 23.15 & 12.33 & 190.76 \\
\hline 26 & NDO-46 & 7.27 & 47.33 & 61.33 & 14.45 & 6.41 & 114.72 & 2.74 & 101.00 & 14.67 & 19.71 & 22.60 & 13.00 & 198.36 \\
\hline 27 & NDO-47 & 6.42 & 43.33 & 54.33 & 15.04 & 5.36 & 120.78 & 2.54 & 105.33 & 13.59 & 20.52 & 22.34 & 11.33 & 207.86 \\
\hline 28 & NDO-48 & 7.81 & 46.00 & 57.33 & 13.82 & 6.80 & 111.45 & 2.70 & 101.67 & 13.49 & 18.49 & 23.13 & 12.67 & 181.61 \\
\hline 29 & NDO-49 & 6.62 & 44.00 & 55.00 & 15.19 & 5.45 & 129.30 & 3.67 & 98.33 & 13.56 & 19.59 & 23.23 & 12.00 & 168.93 \\
\hline
\end{tabular}




\begin{tabular}{|c|c|c|c|c|c|c|c|c|c|c|c|c|c|c|}
\hline 30 & NDO-50 & 7.25 & 44.33 & 55.33 & 11.48 & 6.49 & 106.17 & 3.65 & 96.33 & 12.77 & 21.51 & 22.97 & 12.33 & 155.78 \\
\hline 31 & NDO-51 & 6.50 & 43.00 & 54.33 & 14.12 & 6.41 & 104.54 & 2.85 & 102.67 & 12.69 & 22.25 & 24.03 & 12.67 & 150.71 \\
\hline 32 & NDO-52 & 7.63 & 47.00 & 58.00 & 14.23 & 5.42 & 113.43 & 2.82 & 101.00 & 14.71 & 19.49 & 23.23 & 13.00 & 160.56 \\
\hline 33 & NDO-53 & 8.02 & 42.67 & 54.00 & 13.74 & 5.53 & 112.70 & 2.52 & 104.00 & 14.82 & 18.52 & 24.37 & 13.00 & 170.33 \\
\hline 34 & Arka Anamika (C) & 6.52 & 45.67 & 55.33 & 14.53 & 6.71 & 118.56 & 3.34 & 103.33 & 14.37 & 18.45 & 28.08 & 12.00 & 175.56 \\
\hline 35 & Arka Abhay @) & 6.75 & 42.00 & 53.00 & 15.93 & 5.56 & 113.11 & 3.69 & 98.00 & 12.76 & 18.63 & 24.52 & 13.00 & 160.60 \\
\hline \multirow[t]{8}{*}{36} & VRO-6 (C) & 6.23 & 45.33 & 54.67 & 14.45 & 5.33 & 118.45 & 3.67 & 102.00 & 13.71 & 19.49 & 24.60 & 12.67 & 192.41 \\
\hline & Minimum & 6.19 & 41.67 & 52.67 & 11.48 & 5.33 & 104.54 & 2.33 & 94.33 & 12.53 & 17.76 & 20.63 & 10.67 & 150.71 \\
\hline & Maximum & 8.06 & 48.67 & 61.33 & 16.37 & 6.80 & 129.30 & 3.89 & 108.33 & 14.88 & 22.93 & 28.08 & 13.67 & 210.79 \\
\hline & Grand Mean & 7.19 & 44.51 & 55.06 & 14.24 & 6.02 & 114.58 & 3.23 & 101.60 & 13.63 & 20.19 & 23.02 & 12.21 & 186.25 \\
\hline & C.D.at 5\% & 0.53 & 1.36 & 2.30 & 1.08 & 0.36 & 9.08 & 0.34 & 11.12 & 0.36 & 0.60 & 3.04 & 1.76 & 2.67 \\
\hline & SE(m) & 0.19 & 0.48 & 0.81 & 0.38 & 0.13 & 3.21 & 0.12 & 3.92 & 0.13 & 0.21 & 1.07 & 0.62 & 0.94 \\
\hline & SE(d) & 0.26 & 0.68 & 1.15 & 0.54 & 0.18 & 4.54 & 0.17 & 5.55 & 0.18 & 0.30 & 1.51 & 0.87 & 1.33 \\
\hline & C.V. & 4.48 & 1.87 & 2.56 & 4.63 & 3.71 & 4.85 & 6.38 & 6.69 & 1.61 & 1.83 & 8.04 & 8.76 & 0.88 \\
\hline
\end{tabular}

Table.3 Estimation of coefficient of variations (phenotypic and genotypic), heritability (in broad sense) and genetic advance in percent of mean for thirteen character in okra

\begin{tabular}{|l|l|l|l|l|l|l|}
\hline $\mathbf{S . n o}$ & & $\mathbf{G C V}(\boldsymbol{\%})$ & $\mathbf{P C V}(\boldsymbol{\%})$ & GCV: PCV & $\begin{array}{c}\text { Heritabilitybroad } \\
\text { sense (h2bs) }\end{array}$ & $\begin{array}{c}\text { Genetic } \\
\text { Advance in per } \\
\text { cent of mean }\end{array}$ \\
\hline $\mathbf{1}$ & Node to first flower appearance & 7.30 & 8.57 & 85.25 & 72.68 & 12.82 \\
\hline $\mathbf{2}$ & Days to 50 \% flowering & 4.19 & 4.59 & 91.32 & 83.39 & 7.89 \\
\hline $\mathbf{3}$ & Days to first fruit harvest & 2.83 & 3.81 & 74.09 & 54.89 & 4.31 \\
\hline $\mathbf{4}$ & Fruit length (cm) & 8.77 & 9.91 & 88.45 & 78.24 & 15.98 \\
\hline $\mathbf{5}$ & Fruit circumference (cm) & 8.18 & 8.98 & 91.09 & 82.97 & 15.36 \\
\hline $\mathbf{6}$ & Plant hight (cm) & 3.43 & 5.94 & 57.69 & 33.28 & 4.07 \\
\hline $\mathbf{7}$ & Number of branches per plant & 14.92 & 16.23 & 91.95 & 84.54 & 28.27 \\
\hline $\mathbf{8}$ & Crop duration (days) & 2.27 & 6.29 & 36.04 & 12.99 & 1.68 \\
\hline $\mathbf{9}$ & Petiole length (cm) & 5.79 & 6.01 & 96.33 & 92.80 & 11.49 \\
\hline $\mathbf{1 0}$ & Average fruit weight (g) & 7.16 & 7.39 & 96.88 & 93.86 & 14.29 \\
\hline $\mathbf{1 1}$ & Node per plant & 2.69 & 8.47 & 31.77 & 10.09 & 1.76 \\
\hline $\mathbf{1 2}$ & Number of fruits per plant & 2.92 & 9.23 & 31.66 & 10.03 & 1.91 \\
\hline $\mathbf{1 3}$ & Total fruit yield per plant (g) & 9.32 & 9.36 & 99.57 & 99.13 & 19.11 \\
\hline
\end{tabular}




\section{References}

Burton G.W. and de Vane E.H. (1953). Estimated heritability in tall replicated clonal material. Agron. J. 1953; 45:474-478.

Chandramouli B., Shrihari D., Rao A.V.D. and Rao M.P. (2016). Studies on genetic variability, heritability and genetic advance in okra [Abelmoschus esculentus (L.) Monech] genotypes. Plant Archives. 2016; 16(2):679-682.

Hanson G.H., Robinson H.F. and Comstock R.E. (1963). Biometrical studies of yield in segregating population of Korean Iespedeza. Agron. J. 1963; 48:47-90.

Hazra P. and Basu D. (2000). Genetic variability, correlation and path analysis in okra. Annals of Agri. Res. 2000; 21(3):452-453.

Johnson H.W., Robinson H.F. and Comstock R.E. (1955). Genotypic and phenotypic correlation in soybean and their implications in selection. Agron. J. 1955; 47:477-483.

Joshi A.B., Gadwal V.R.and Hardas M.W. (1974). Evolutionary studies in world crops. In Diversity and Change in the Indian Sub-Continent. Hutchinson, J.B. (Ed.), London: Cambridge University. 1974, 90-105.

Kerure P, Pitchaimuthu M. and Hosamani M. (2017). Studies on variability, correlation and path analysis of traits contributing to fruit yield and its components in okra (Abelmoschus esculentus L. Moench). El. J. Pl. Breed. 2017; 8(2):620-625.

Kundu B.C. and BiswasC. (1973) Anatomical characters for distinguishing Abelmoschus spp. and Hibiscus spp. Proceed.Indian Sci. Cong. 60:295-298.

Linnaeus C. (1753). Species Plantarum. Stockholm, I, II. Naidu A.K., Verma B.K. and Raut R.L. (2007). Genetic variability studies of yield and its attributing traits in okra [Abelmoschus esculentus (L.) Moench]. International Conference on sustainable Agriculture for food, Bio-energy and livelihood security. 2:467.

Narayan J.R.P, Mulge R., Kotikal Y.K., Patil M.P., Madalageri M.B. and Patil B.R. (2006). Studies on genetic variability for growth and earliness character in okra (Abelmoschus esculentus (L.) Monech). Crop Res. (Hisar). 32(3):411-413

Panse V.G. and Sukhatme P.V. (1984). Statistical Methods for Agricultural Workers. ICAR Publication, New Delhi, 1984, 359

Patel R, Sengupta S.K. and Verma A.K. (2014) Studies on genetic parameters in okra [Abelmoschus esculentus (L.)].Trends in Biosciences. 2014; 7(14):1808-1811.

Terrell E.E. and Wintre H.F. (1974). Change in scientific names for certain crop plants. Horticulture Science. 9:324325.

\section{How to cite this article:}

Shalu Yadav, Vijay Bahadur Singh, Gulab Chand Yadav and Aniket Kumar Verma. 2020. Studies on Extent of Variability, Heritability and Genetic Advance in Okra [Abelmoschus esculentus (L.) Moench]. Int.J.Curr.Microbiol.App.Sci. 9(10): 54-59. doi: https://doi.org/10.20546/ijcmas.2020.910.008 